\title{
Climate Smart Agriculture, need for 21st century to achieve socio-economic and climate resilience agriculture in India: A geospatial perspective
}

\author{
Firoz Ahmad ${ }^{1}$, Nazimur Rahman Talukdar ${ }^{2,3}$, Meraj Uddin ${ }^{4}$, Laxmi Goparaju ${ }^{1 *}$ \\ ${ }^{1}$ Vindhyan Ecology and Natural History Foundation, Mirzapur, Uttar Pradesh, India \\ *e-mail: goparajulaxmi@yahoo.com \\ ${ }^{2}$ Wildlife Conservation Laboratory, Department of Ecology and Environmental Science, Assam University, \\ Silchar, India-788011 \\ ${ }^{3}$ Centre for Biodiversity and Climate Change Research, Udhayan, Hailakandi-788155 \\ ${ }^{4}$ University Department of Mathematics, MCA, Ranchi University, Ranchi, Jharkhand, India
}

Received: 8 November 2019 / Accepted: 15 December 2019

\begin{abstract}
Climate change is now widely recognized as the major environmental threat occurring mainly due to increasing greenhouse gases in the atmosphere and causing the extinction of biodiversity and enhances disruptions to ecosystems. Climate change risks are found to be very significant and would have a profound impact on the livelihoods of millions of poor people in India. In the present study, we have analyzed datasets of agriculture Greenhouse gases (GHGs) emission (1990-2016), poverty, anthropogenic biomes, agriculture crop production scenario (2008-2017), seasonal soil moisture status present (2006-2015) and deficit (compared with 20 years' time periods), present (1970-2000) annual mean, future (2050) precipitation and temperature scenario of India and investigated the spatial pattern and relationship incorporating in remote sensing and GIS for the better comprehension of the impact of climate changes on the socio-economic dimension of the people. The total GHGs emissions ( $\mathrm{CO}_{2}$ equivalent) from agriculture in India were showing the increasing trend (approximately $1 \%$ annually) whereas the increasing trend has decreased notably in the last five years. The states of Bihar, Uttar Pradesh, West Bengal, Assam, Punjab, and Tamil Nadu and Andhra Pradesh of India were found producing higher GHGs emissions from agriculture. The present soil moisture and the deficit during the Kharif, Rabi, and Zaid seasons vary geographically whereas soil moisture deficit during the Kharif season was found very significant over most of the districts of Ganga and Brahmaputra basin. The present mean annual temperature and precipitation patterns were found very significant in arid and semi-arid regions which are known as the farmer's suicide hotspot and are predicted to threaten more in the future (2050). The evaluation highlights the need for synergic approaches such as climate-smart agriculture (CSA) to address the impact of climate change in food production and farmers' livelihood. Such an investigation gives a solid understanding of a paradigm shift in the adaptation of CSA an approach in prevailing new climate change reality at country or regional levels for achieving socio-economic and climate resilience agriculture in India.
\end{abstract}

Key words: climate, greenhouse gas, India, Remote Sensing, socio-economic, soil moisture.

\section{Introduction}

Climate-smart agriculture (CSA) is an approach for transforming and reorienting agricultural development under the new realities of climate-induced risk (Lipper et al., 2014). Food and Agricultural Organization (FAO) was first floated the word Climate-Smart Agriculture (CSA) in 2010 to address the challenge of food security and demand, liveli- 
hood and the climate change impact with insights in technical, institutional, policy and financial responses which will meaningfully transform agriculture in developing countries (FAO, 2010). The World Bank (2018) has defined CSA is an integrated approach to managing landscapes/cropland to achieve the three important goals:

1. Enhancing productivity in terms of food to boost the income of poor people and to provide nutrition and livelihood security especially in rural fringe mainly depends on agriculture.

2. Increasing resilience for reducing risk to drought, pests and diseases, and building capacity to transform in the face of longer-term stresses.

3. Minimizing GHGs emissions in food production and with an aim to avoid deforestation and identify the mechanism to reduce carbon from the atmosphere.

The CSA is extremely important around the globe, especially in developing countries, including India. The majority of farmers in India are from weak socio-economic backgrounds and suffering from difficulties due to increasing cost of cultivation (chemicals, seeds and equipment) (Sadashiv, 2015). This has been increasing several folds because of climate-induced risk in agriculture (Goparaju $\&$ Ahmad, 2019) i.e., the increase in temperatures (Sharma, 2018), abrupt rainfall patterns (World Bank, 2013), floods (Josh, 2018), frequent droughts (Tyalagadi et al., 2015), water deficiency (Pangaluru et al., 2019) which in the majority of the case leads to crop failure. Furthermore, cropland in India is suffering because of fertility depletion (Aggarwal, 2018), erosion (Oldeman et al., 1991), and water stress (Shiao et al., 2015). In recent studies based on long term NDVI, it was observed most of the vegetation (agriculture and the forest) in India is losing its greenness (Chakraborty et al., 2018; Ahmad et al., 2019a) which manifest their degradation.

India has signed the Paris Agreement in November 2016 with the basic aim to reduce the GHGs emission whereas agriculture is the second-largest contributor to GHGs emission after the energy sector (Patra \& Babu, 2017). The future climate-induced risks to farmers in India will be more severe (Goparaju \& Ahmad, 2019). Such challenges need concrete synergic strategies from local to national levels. Climate-Smart Agriculture has the potentiality to overcome such challenges (Lipper et al., 2014) and can be stretched from village to country-level if it is adequately supported by grants, technical knowledge, and well-defined guideline (Goparaju \& Ahmad, 2019).

The aim of the study was to evaluate the importance of CSA using socio-economic and climatic datasets, and examine spatial pattern or relationship in GIS for the better comprehension of the impact of climate change and the socio-economic dimension of the people. Such an investigation gives a solid understanding of a paradigm shift in the adaptation of CSA an approach in the prevailing new climate changes the reality for achieving socio-economic and Climate resilience agriculture in India.

\section{Methodology}

In the present study, we have used several datasets (Table 1) such as GHGs emission from agriculture (FAO, 2019), the percentage of people living Below Poverty Line (BPL) (Lewis, 2013), anthropogenic biomes of India as transformed by sustained human population density and land use (Ellis et al., 2013), major agriculture crop production (2008-2017) (FAO, 2019), Terra Climate a high spatial resolution (4-km) monthly global dataset of soil moisture (Abatzoglou et al., 2018), present and future climate data (Fick \& Hijmans, 2017), ancillary datasets and literature for the better understanding of GHG emission, socioeconomic condition, anthropogenic biomes, seasonal (Kharif, Rabi, and Zaid) soil moisture distribution pattern and the deficit, major agriculture crop production scenario, present, and future impact of climate change. The procedures we have followed are rectification, digitization to bring the percentage of people living Below Poverty Line and anthropogenic biomes map of India into the GIS domain (Ahmad \& Goparaju, 2017). The monthly soil moisture data were arranged systematically (Zhao \& Siebert, 2015) for generating (decadal monthly average) their pattern (district wise) for three seasons of India. Furthermore, we have generated season-wise soil moisture deficit by comparing it with the past decadal monthly average (1976-1985). The present (1971-2000) climate data such as annual mean temperature $(\mathrm{BIO} 1)$ and annual mean precipitation (BIO12) were

Table 1. Various datasets and their sources used in this study

\begin{tabular}{|l|c|}
\hline \multicolumn{1}{|c|}{ Data used } & Source/References \\
\hline GHG emission from agriculture & FAO (2019) \\
\hline $\begin{array}{l}\text { Percentage of people living Below } \\
\text { Poverty Line (BPL) }\end{array}$ & Lewis (2013) \\
\hline $\begin{array}{l}\text { Anthropogenic biomes of India as } \\
\text { transformed by sustained human } \\
\text { population density and land use }\end{array}$ & Ellis et al. (2013) \\
\hline $\begin{array}{l}\text { Major agriculture crop production (2008- } \\
\text { 2017) }\end{array}$ & FAO (2019) \\
\hline $\begin{array}{l}\text { Terra Climate a high resolution global } \\
\text { dataset of monthly soil moisture }\end{array}$ & $\begin{array}{c}\text { Abatzoglou et al. } \\
(2018)\end{array}$ \\
\hline $\begin{array}{l}\text { Present and future climate data } \\
\text { Fick and Hijmans } \\
(2017)\end{array}$ \\
\hline
\end{tabular}


analyzed to investigate the future district wise trends in the states of India (2050). The Erdas Imagine and Arc GIS software were adequately utilized whenever and wherever it required for achieving the aims and objectives of the study.

\section{Results}

\subsection{Greenhouse gases (GHGs) emission from agriculture}

Analysing data revealed that total GHGs emissions from agriculture in India have been increasing annually at a rate of approximately $1 \%$, however, since 2011, the GHGs emission has been in a stable condition (Fig. 1). The state of Bihar, Uttar Pradesh, West Bengal, Assam, Haryana, and Punjab were the main contributors to GHGs emissions. Among the different sectors of agriculture, GHGs emission from enteric fermentation was highest between the periods of 1990-2016, followed by rice cultivation, synthetic fertilizers, manure left on pasture, manure management, crop residues, and burning-crop residues.

\subsection{Anthropogenic biomes and major agriculture crop production scenario}

By 2000, the majority of land use land cover had been transformed into rangelands, croplands, villages leaving significant low of the terrestrial biosphere virgin and seminatural (Fig. 2) The rice villages were found significantly higher in the state of Bihar, Uttar Pradesh, West Bengal, Assam, Punjab, and Tamil Nadu and Andhra Pradesh whereas irrigated villages were significantly higher in Haryana (Fig. 2). Most of these states and their districts were the major sources of GHGs emission between the study periods. Evaluating the major agriculture crop production in India between the periods 2008 and 2017, it has been revealed that the annual mean production of rice, wheat, maize, pulses, sunflower seeds, sugar cane, and potato were $154.85,88.85,22.78,0.88,0.54,333.91$ and 42.12 million tons respectively (Fig. 3 ).

\subsection{Socio economic scenario}

The socio-economic status of the states in India is shown in Figure 4. It has been revealed that $26.7 \%$ of the total districts of India have $0-10 \%$ populations living in

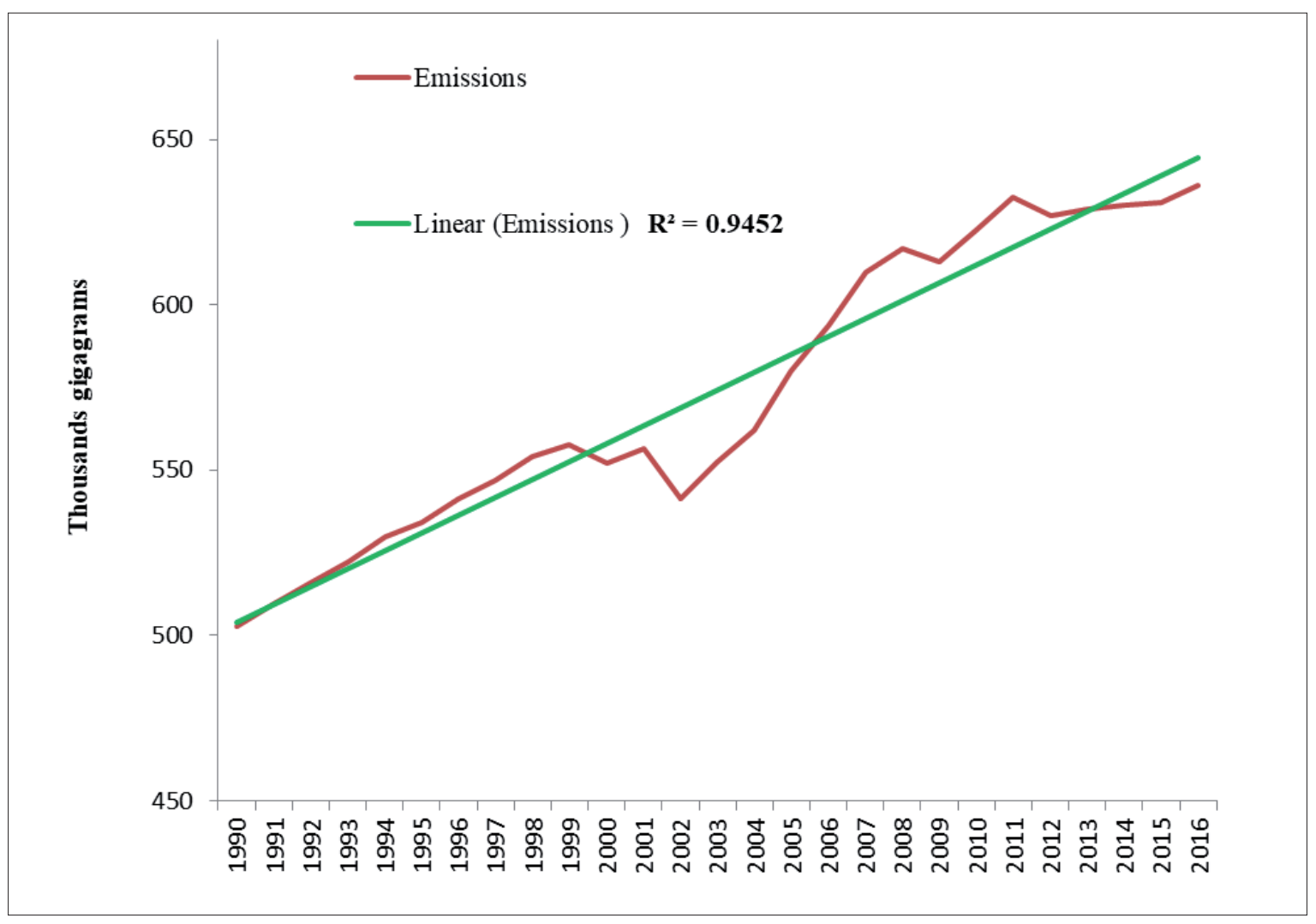

Figure 1. Total emissions of GHGs from agriculture ( $\mathrm{CO}_{2}$ equivalent) between 1990 and 2016 in India (FAO, 2019) 
poverty lines, $18.8 \%$ districts have $11-20 \%$ populations living below poverty lines, $18.8 \%$ of districts have $21-30 \%$ populations living below poverty lines, $16.7 \%$ of districts have $31-40 \%$ populations living below poverty lines and $19 \%$ of the districts have $41-80 \%$ populations living below poverty lines. The significantly high poverty percent are dominant in the majority of states such as Odisha, Chhattisgarh, Bihar and Madhya Pradesh.

\subsection{Soil moisture scenario during major cropping season}

The investigation of long-term district wise soil moisture present (2006-2015) and deficit (comparing it with 20 years back decadal (1976-1985) data) during the Kharif (Fig. 5), Rabi (Fig. 6) and Zaid season (Fig. 7) highlights the interesting trend. During the Kharif season, soil moisture was found considerably high in coastal districts of the Western Ghats, North-Eastern districts and North-Eastern districts of Central India. Low soil moisture was found in the majority of arid and semi-arid area's districts. Soil moisture deficit during the Kharif season was found very significant over most of the districts of Ganga and Brahmaputra basin.

The district-wise soil moisture pattern during Rabi season was found very similar to the pattern of the Kharif season except in few districts of Tamil Nadu and Andhra Pradesh where the soil moisture appreciably improved while comparing it with the Kharif season. Soil moisture deficit was found more pronounced during Rabi season while comparing it with the Kharif season and further overtaken some more districts of the southeastern part and all

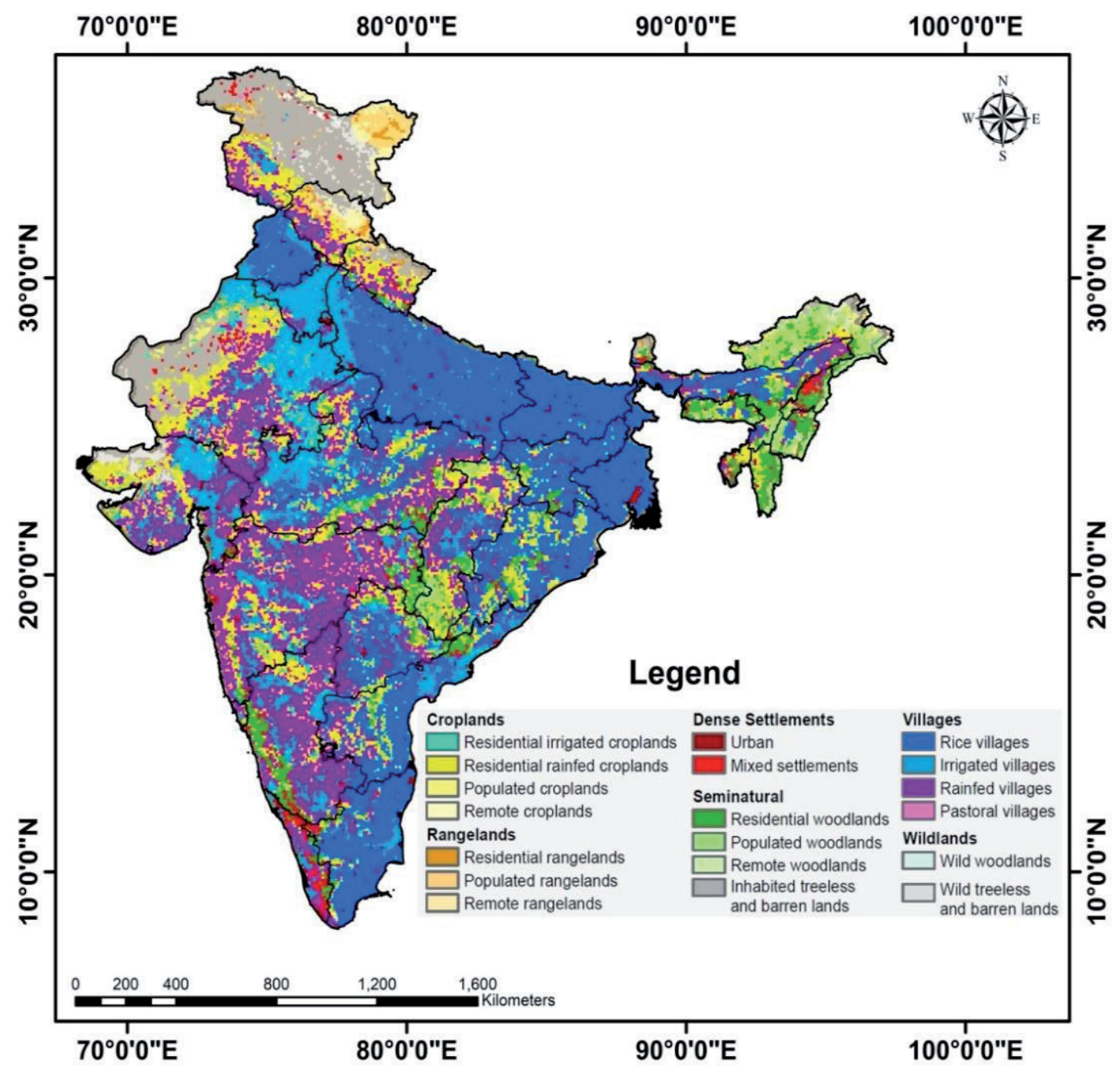

Figure 2. Anthropogenic biomes for the year 2000 of India describe potential natural vegetation, biomes, as transformed by sustained human population density and land use including agriculture and urbanization (Ellis et al., 2013) 


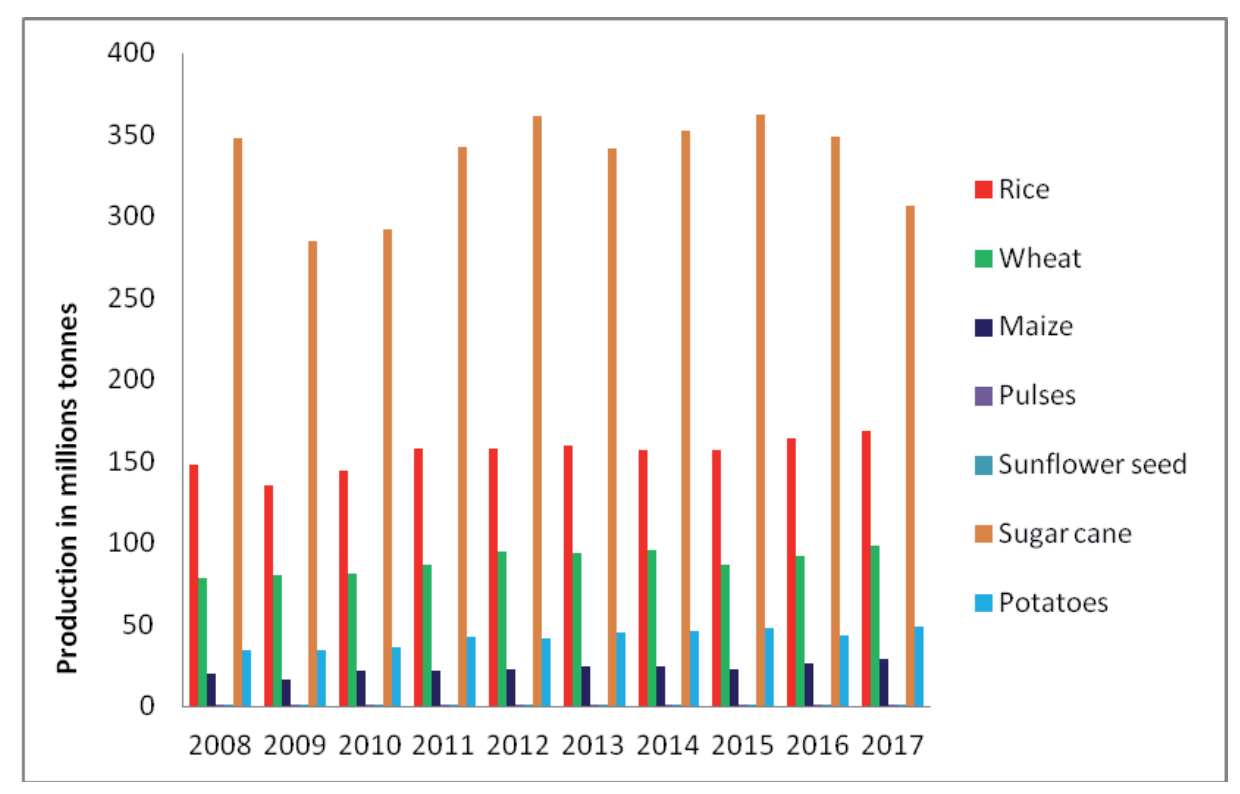

Figure 3. Major agriculture crops production (2008-2017) in India (FAO, 2019)

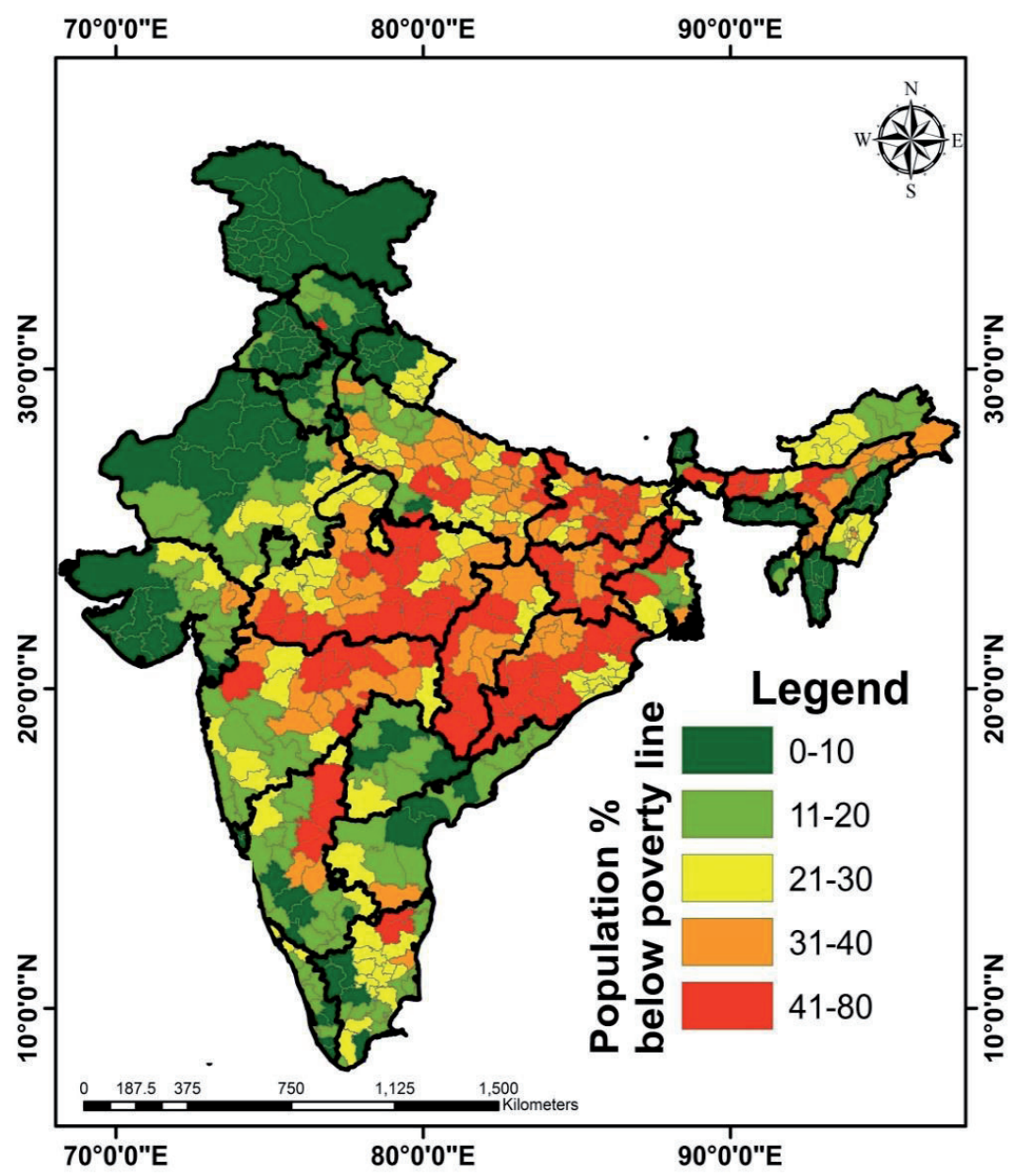

Figure 4. District wise percentage of people living Below Poverty Line (BPL) (Lewis, 2013) 


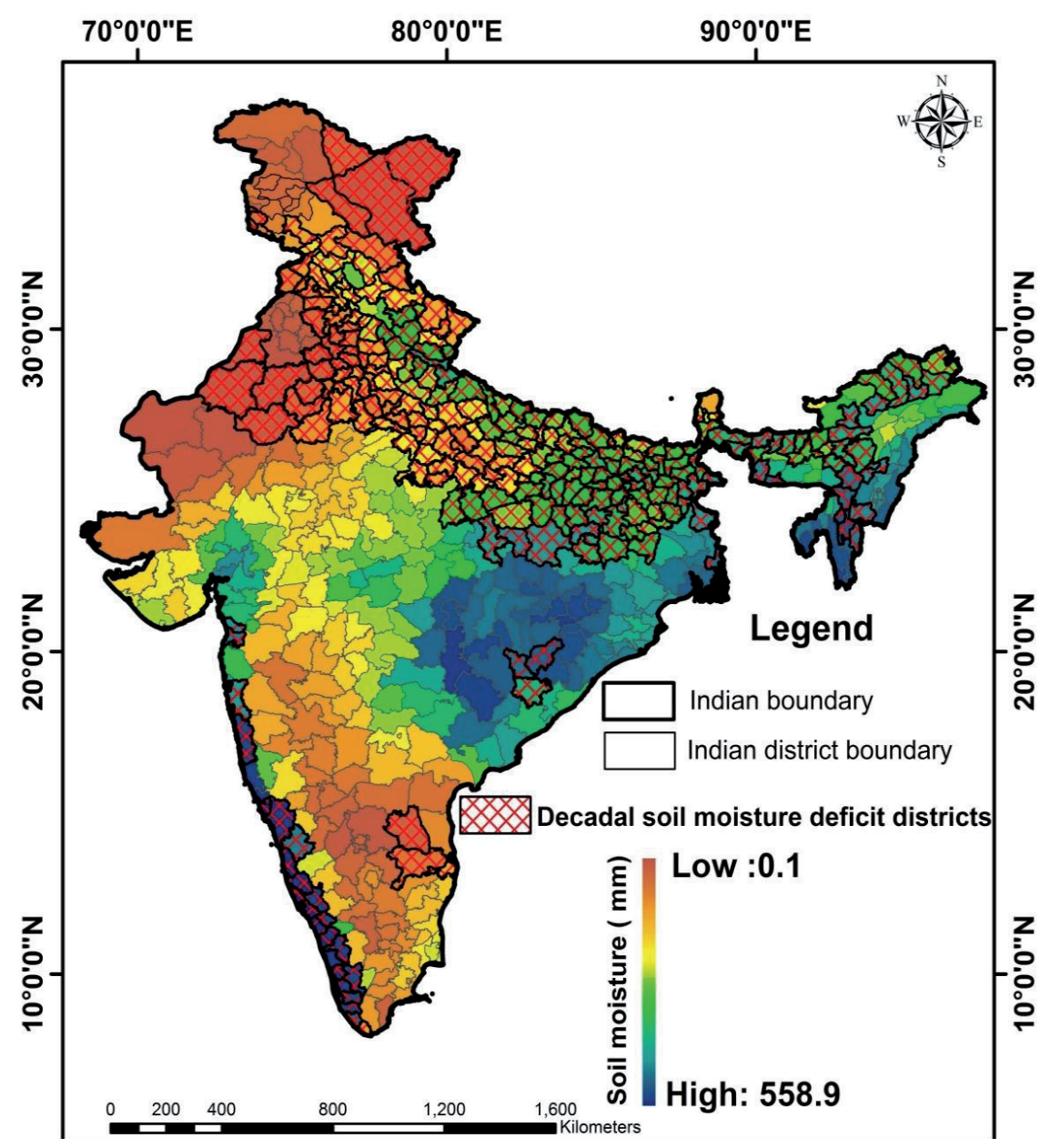

Figure 5. Soil moisture pattern (district wise) of Kharif season (present decadal monthly average: 2006-2015) overlaid with soil moisture deficit (compared with past 20 years back decadal monthly average: 1976-1985) districts of India

districts of North East of India. The deficit patterns during this season were more in the northern districts of India. Soil moisture in all seasons was found good in some of the highest tribal-dominated districts of northeast states (Chhattisgarh, Jharkhand and Orissa) as shown in Figure 5,6 , and 7 (blue to green colour in the map).

\subsection{Climate data present and future scenario}

The investigation of the present long term (1971-2000) annual mean of temperature and precipitation and their future (2050) trends were observed (Fig. 8 and Fig. 9). The present mean annual temperatures as well as precipitation pattern were found very remarkable in arid and semi-arid regions. The future precipitation deficits were also observed over part of the Western Ghats which are known for rich biodiversity and agriculture production (Kumar \& Takeuchi, 2009).
Approximately $70 \%$ of the country's geographical area will face more or less threat by 2050 due to an increase in temperature $\left(>2^{\circ} \mathrm{C}\right)$ and deficit in precipitation patterns. The major agriculture producing states of India such as Kerala, Karnataka, Punjab, Haryana, Assam, Chhattisgarh, Bihar, West Bengal, Telangana and parts of Gujarat and Maharashtra will face more climate-induced risk that can significantly impact future agriculture production.

\section{Discussion}

\subsection{Greenhouse gases (GHGs) emission from agriculture}

Growing international concern and cooperation regarding the climate change problem have increased the need to consider the uncertainty in inventories of GHG emissions. 


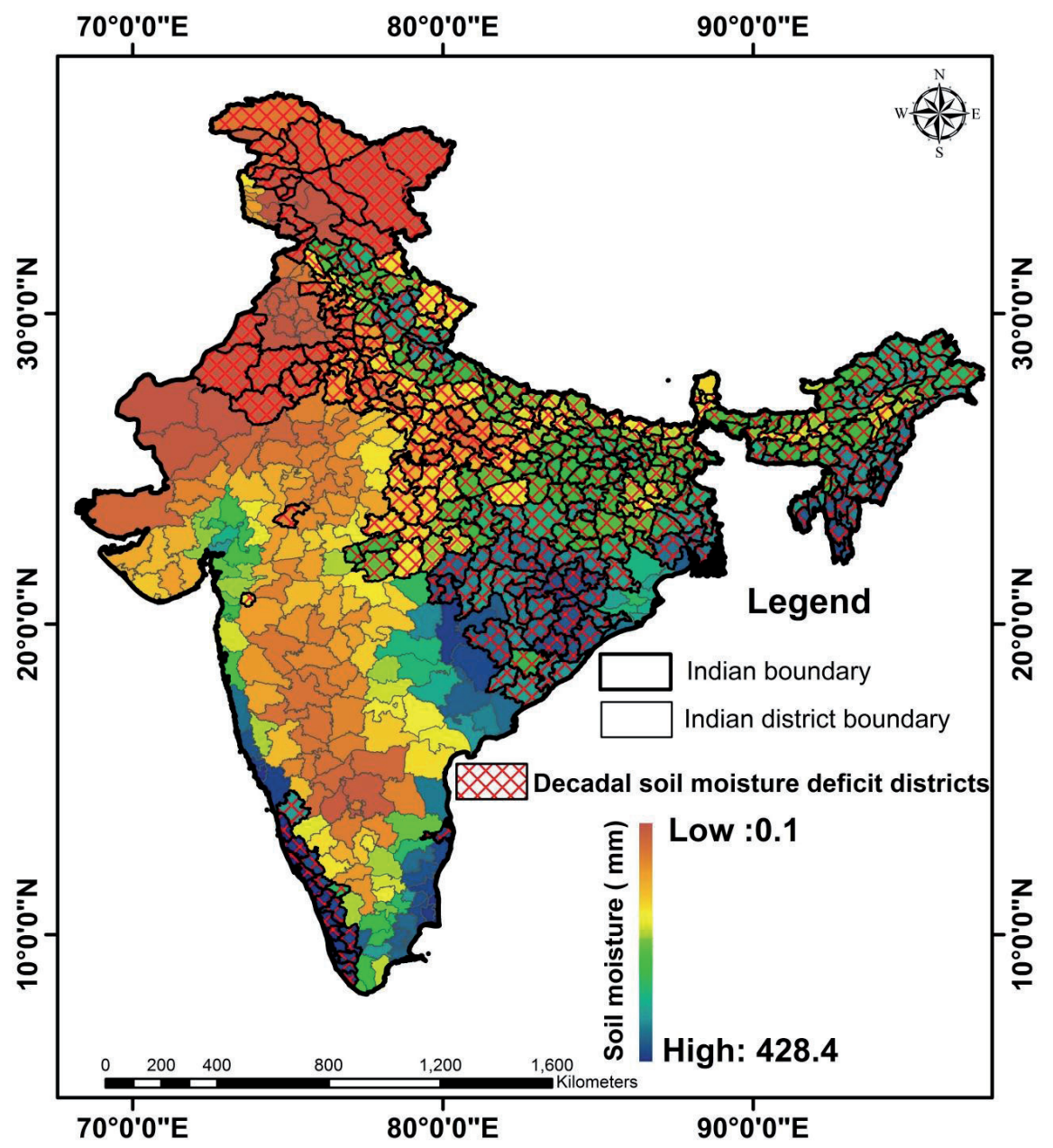

Figure 6. Soil moisture pattern (district wise) of Rabi season (present decadal monthly average: 2006-2015) overlaid with soil moisture deficit (compared with past 20 years back decadal monthly average: 1976-1985) districts of India

Greenhouse gases such as carbon dioxide $\left(\mathrm{CO}_{2}\right)$, methane $\left(\mathrm{CH}_{4}\right)$ and nitrous oxide $\left(\mathrm{N}_{2} \mathrm{O}\right)$ are increasing significantly these days on the earth surface leading to increasing the global mean temperature and creating a risk of climate change and associated extreme climatic events (IPCC, 2007; 2014). Agriculture activities contribute approximately $29 \%$ of GHGs emissions (CGIAR, 2012). We have evaluated the long term (1990-2016) total emissions ( $\mathrm{CO}_{2}$ equivalent) from agriculture in India, which is given in Figure 1. GHGs emission from Indian agriculture was found increasing continuously at a rate of $1 \%$ although it has become stabilized since 2011. The majority of the GHGs emissions were contributed by Ganga and Brahmaputra basin sprawling over five major agricultural states. Similar results were revealed from the study by Patra \& Babu (2017) and Carlson et al. (2016). The GHGs emissions from cultivated cropland are very significant in the Ganga-Brahmaputra basin (Carlson et al., 2016) which are highly fertile land and support crucially in food security and livelihood of most poor people (Kumar, 2017). Almost half of the total agricultural GHGs emissions were from enteric fermentation as India is the top cattle producer in the world (Indexmundi, 2019) which contributes a large section of $\mathrm{CH}_{4}$. Rice is the most cultivated crop in India, which was found as the second-largest contributor to GHGs emissions. Other sectors of agriculture such as synthetic fertilizers $(14.3 \%)$, manure left on pasture $(10.5 \%)$, manure management $(4.7 \%)$, crop residues $(3.7 \%)$ and burning crop residues $(0.6 \%)$ contributed to the remaining fraction of total agricultural GHGs emissions (FAO, 2019).

\subsection{Anthropogenic biomes and major agriculture crop production scenario}

Humans population have altered the form and process of many ecosystems across the Earth's biosphere as per as 


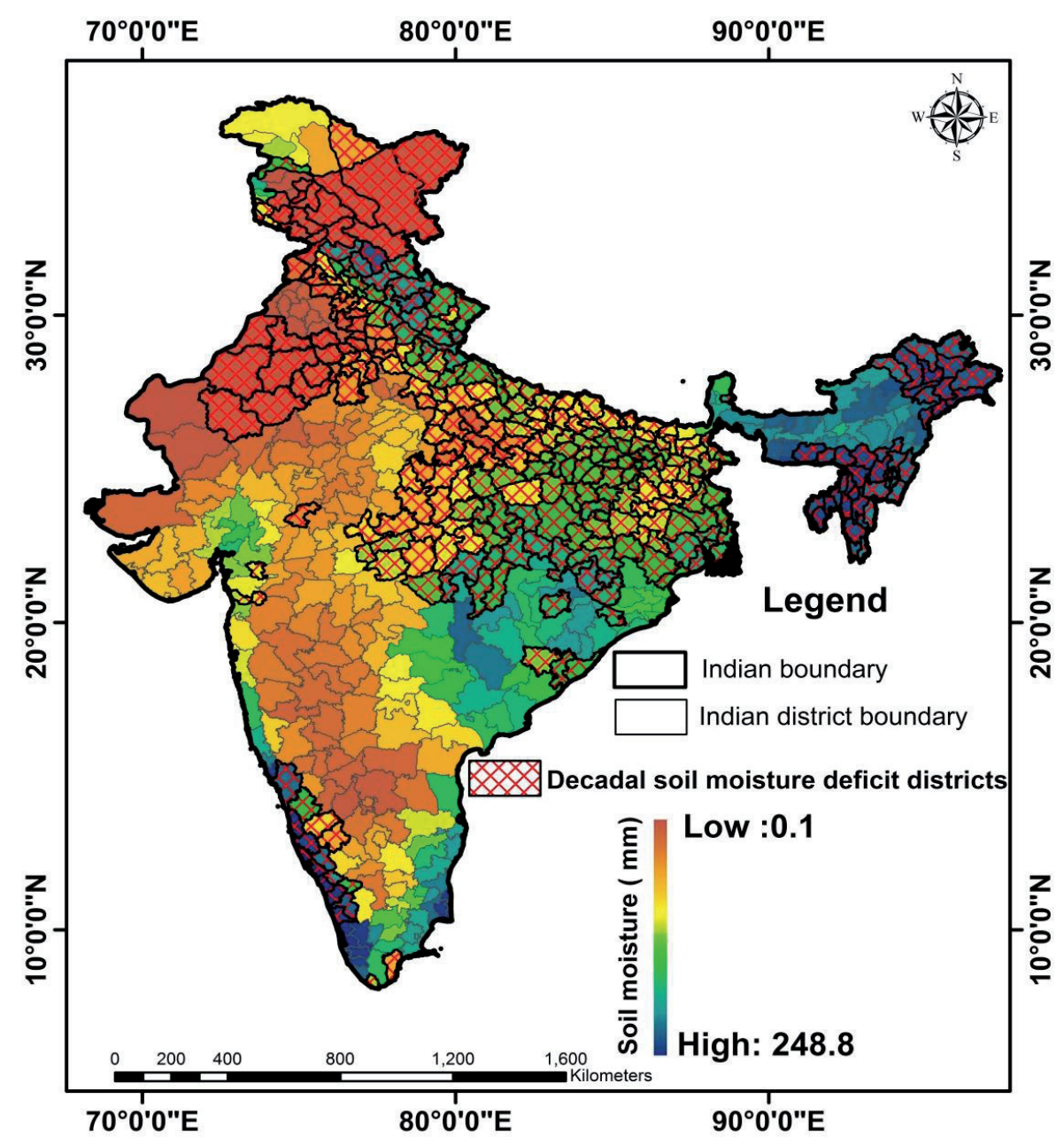

Figure 7. Soil moisture pattern (district wise) of Zaid season (present decadal monthly average: 2006-2015) overlaid with soil moisture deficit (compared with past 20 years back decadal monthly average: 1976-1985) districts of India

their needs in due course of time (Dearing et al., 2006; Ellis et al., 2010). Results of the study show that the significant land-use transformations in the anthropogenic biomes had been taken place by 2000 of India. This is due to the large-scale implication of the Green Revolution after the 1970s, which resulted in the conversion of natural forest lands into rangelands and croplands (Ellis et al., 2010). Most of such converted areas were used for rice, wheat and maize cultivation in the states of Bihar, Uttar Pradesh, West Bengal, Assam, Punjab, and Tamil Nadu, Andhra Pradesh and Haryana (Fig. 2). The majority of these states and their districts are the major sources of GHGs emission (Carlson et al., 2016; Patra \& Babu, 2017). These lands are the major sources of the country's food production. Most of the agricultural lands in India have not facilitated through the irrigation system and hence the Kharif crops are dependent on monsoonal rainfall. The changing nature of the In- dian monsoon because of climate change (Goswami et al., 2016) influences production (Prasanna, 2014). The agriculture crop production needs to be increased remarkably by adopting the high yielding varieties of climate-resilience crops (FAO, 2012) to meet the future food demand.

\subsection{Socio economic scenario}

Socioeconomic aspects of the people are important as a CSA adaptation strategy (Howland et al., 2018). As per the World food programme, India carries an enormous burden of food insecurity (over 195.9 million people) despite some improvements in the nutritional status of children but still below acceptable levels whereas the micronutrient deficiencies are alarming as India ranks 103 out of 119 countries (WFP, 2019). India is the country where the smallholder farming community numbers are significantly high. 


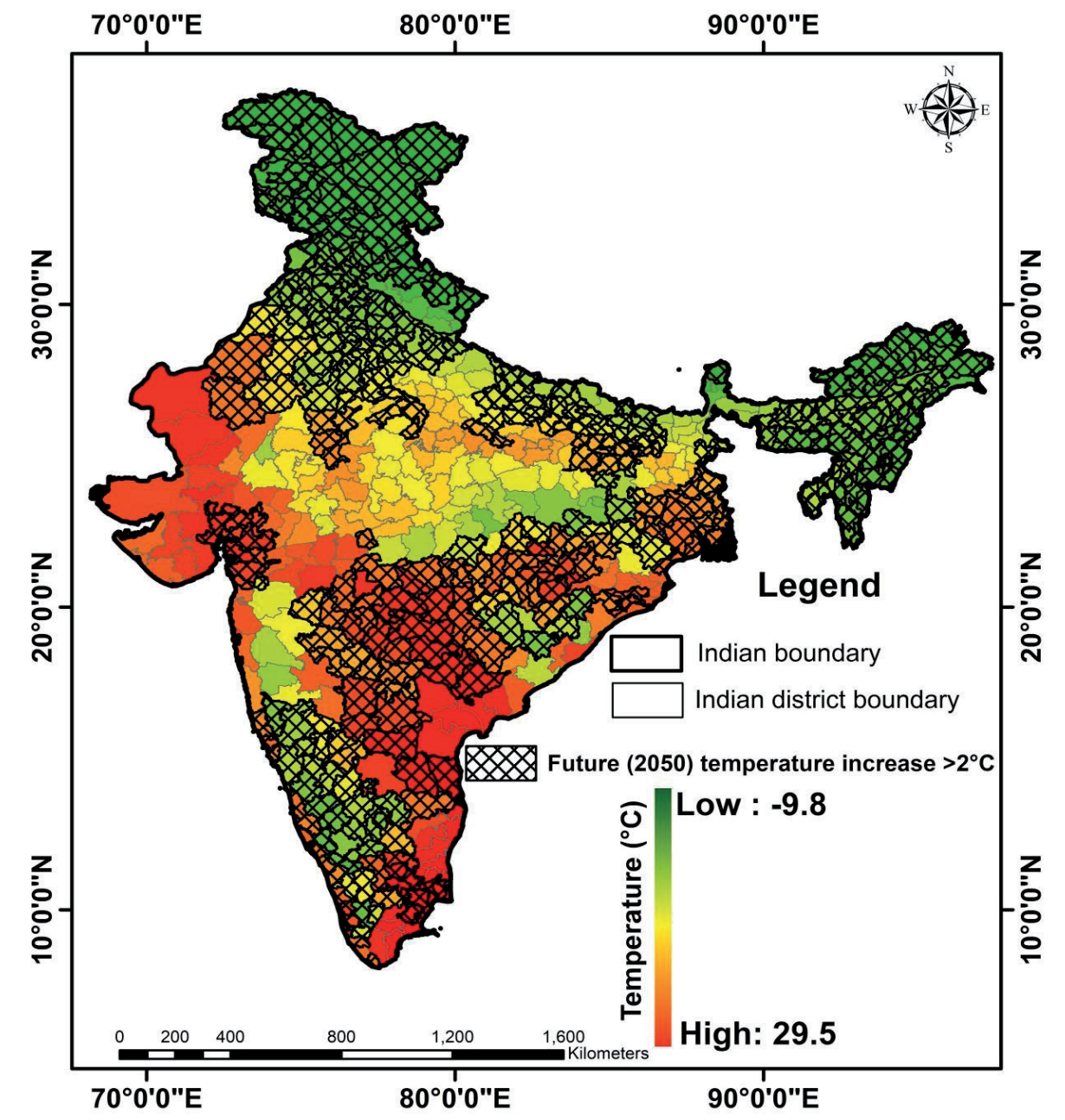

Figure 8. Annual mean temperature (BIO1) present (1971-2000) scenario overlaid with future (2050) temperature $\left(>2^{\circ} \mathrm{C}\right)$ increase (Predictive Modeling: HD $4.5 \mathrm{RCP}$ scenario) (Fick \& Hijmans, 2017)

They are suffering from poverty and have a weak socioeconomic condition. The conditions in the rural area are more critical. The $70 \%$ of Indian populations are poor and found in the rural area, whereas $75 \%$ of India's family depends on rural income (World Bank, 2013). Reducing rural poverty is one of the biggest challenges and needs an adequate strategy to support long-term benefit to the poor, landless, women, scheduled castes and tribes which are having the weak adaptive capacity to climate change. The analysis of poverty map (Fig. 4) crucially manifested that the eastern part of central India such as districts of Chhattisgarh, Orissa, and Jharkhand have a high percent of the people living below the poverty line and these percent further increases in the vicinity of the forest dominated tribal area (Ahmad et al., 2018; Ahmad et al., 2019b). Tribal are more vulnerable to climate change (Minj, 2013) whereas some farmer's suicidal hotspot districts (Goparaju \& Ah- mad, 2019) of central India needs special priority in implementing the CSA because apart from other factors the severity of the Hunger Index are found alarming (Menon et al., 2009). Women role in CSA is well recognized in the term of their active participation in farm output and their endowment to food security (Agarwal, 2013; KhatriChhetri et al., 2019). The socio-economic issues with the gender-gap need to be critically evaluated for adequate priorities for selecting the area for CSA implementation (World Bank Group, FAO and IFAD, 2015; Goparaju \& Ahmad, 2019). Such an evaluation process provides a technical understanding of CSA options to establish realistic pathways for enhancing the CSA adoption strategies (Corner-Dolloff, 2014). 


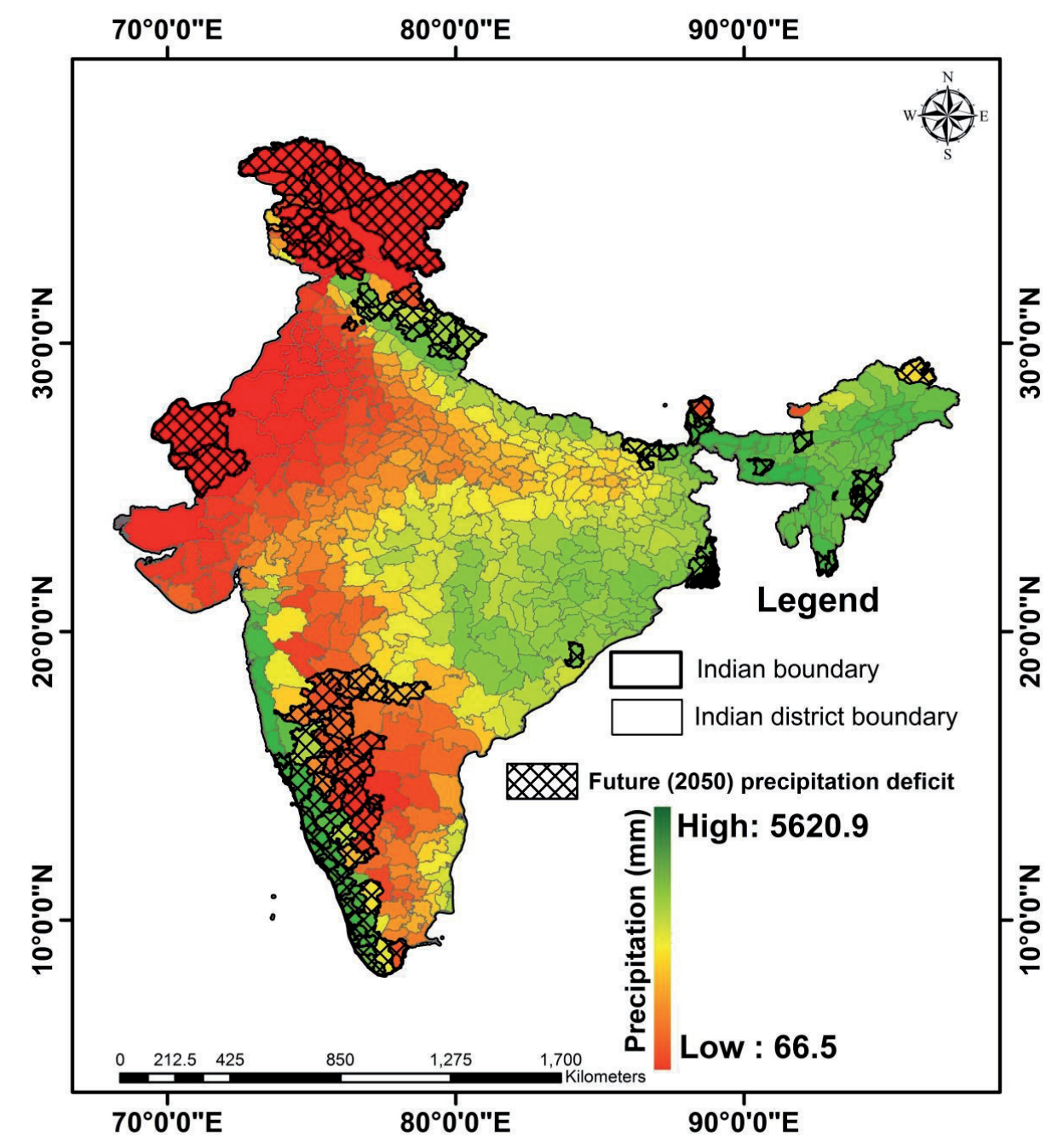

Figure 9. Annual mean precipitation (BIO12) present (1971-2000) scenario overlaid with future (2050) precipitation deficit (Predictive Modeling: HD 4.5 RCP scenario) (Fick \& Hijmans, 2017)

\subsection{Soil moisture scenario during the major cropping season}

Soil moisture is one of the important parameters which regulate the nutrient uptake in crops and influence the agricultural production (Sikka et al., 2018) and provides adequate information for the improvement of the irrigation system, supervising the flood risk, assessment of agricultural drought and weather forecast for irrigation (Sebastian, 2019). Soil moisture in the Kharif season was found highest in the Western Ghats and north-eastern states while arid and semi-arid regions were found in low soil moisture content. This is due to the fact former two regions are high rainfall areas of the country whereas rainfall in the latter areas are considerably low. Soil moisture deficit during the Kharif season in the districts of Ganga and Brahmapu- tra basin was found significantly higher. This basin retains a significantly high population (630 million inhabitants) and continuously facing anthropogenic pressure on land use land cover (LULC) whereas the seasonal rainfall is also showing a decreasing trend (Kumar \& Ambastha, 2016; Diwakar et al., 2017) is the probable appropriate reason of soil moisture deficit.

Comparing with Kharif season in the district wise dataset of soil moisture, it was revealed that Rabi season was also similar to the pattern of Kharif season. However, soil moisture in a few districts of Tamil Nadu and Andhra Pradesh were appreciably improved during Rabi season than the Kharif season. Soil moisture deficit during Rabi season is found more pronounced while comparing it with Kharif season and further overtakes some more 
districts of the southeastern part and all districts of North East of India. Soil moisture during the Zaid season notably reduced (high value: $248.8 \mathrm{~mm}$ ) in the districts of northern states of the country due to an increase in summer temperature (Pandey, 2018). Soil moisture in all the seasons suffering from extreme poverty can be selected for climate-smart agriculture urgently because of their weak adaptive capacity to climate change. A similar analysis of soil moisture was studied by Pangaluru et al. (2019).

The study of soil moisture scenario is important for crop production (Reichert et al., 2019) and considered as one of the key issues in CSA can be crucially support as a strategy for soil and water conservation for the enhancement of soil moisture. Such strategies are highly useful in low precipitation, rain-fed, moisture deficit area to trap the monsoon rainwater at the watershed level (Sharma, 2009), which in a majority of time goes in vain as runoff loss (http://www.fao.org/docrep/t1696e/t1696e02.htm).

\subsection{Climate data present and future scenario}

Climate change risks are found very significant in India whereas preparations or abilities to respond to the climate changes are inadequate (Bhushan, 2015; WEF, 2018). The climate-induced risks are threatening the crop yields (Goparaju \& Ahmad, 2019) due to increase in temperature (Lal et al., 1995), rainfall (Goswami et al., 2006; Kumar et al., 2010) repeated droughts (Ramanathan et al., 2005), and evidence of periodic floods (World Bank, 2013). Projected impact of climate change based on the trends of temperature and precipitation shows that the impact of climate change will be threatened harshly in the near future (2050) in the arid and semi-arid regions. Carleton (2017) recognized these areas as the farmer's suicide hotspots due to the increasing trend of temperature. Some high poverty districts of the state of Orissa, Chhattisgarh, and Bihar will be threatened in the future. The future precipitation deficits were also observed over part of the Western Ghats which are known for rich biodiversity and also agriculture production (Kumar \& Takeuchi, 2009)

Based on the above study, we can conclude the GHG emission, anthropogenic pressure on LULC, socio-economic condition of people, soil moisture distribution and deficits are found very pronounced in India. The present temperature and precipitation pattern and future trends in India has been found very challenging which might impact the agriculture production in due course of time. Such analysis importantly highlights a need harmonized policy to prioritize the areas suffering from a new climate change reality to support resilience among most of the marginalized people. There is a need to design a tangible policy by the institutional efforts addressing the deep-rooted socioeconomic and climatic problems of agriculture-dependent poor people in all the areas of the country which will sup- port Climate-smart agriculture (CSA) practices based on indigenous knowledge to improve the farm outputs and livelihoods of the people.

\section{Conclusion}

The paper deals with the datasets such as agriculture GHGs emission, poverty, anthropogenic biomes, agriculture crop production scenario, soil moisture status and deficit, present and future precipitation and temperature scenario which give a better understanding of the impact of climate change and socioeconomic dimension on the people. The result highlights the Greenhouse gases total emissions ( $\mathrm{CO}_{2}$ equivalent) from agriculture in India were showing the increasing trend, and it is notably high in riceproducing regions (Carlson et al., 2016). Agriculture crops (2008-2017) such as rice, wheat, maize, pulses, sunflower seeds sugar cane and potato production in India varies annually and largely depends on Indian monsoonal rainfall pattern need to be increased remarkably for future generations. Special priority in implementing the CSA is important which may reduce the future food deficient under the climate change.

Soil moisture is an important variable in the climate system whereas its long term observation is a critical research gap (Robock, 2015) which was first time addressed at the country level of India. The present soil moisture and the deficit during the Kharif, Rabi and Zaid seasons vary in spatial pattern over India whereas soil moisture deficit during the Kharif season was found very notable over most of the districts of Ganga and Brahmaputra basin which provides food security to the millions of poor inhabitants need a synergic strategy for soil and water conservation to enhance the seasonal soil moisture to boost agriculture crops for the future. The present mean annual temperatures, as well as precipitation pattern, were found very significant in arid and semi-arid regions which predominantly identified as the farmer's suicidal hotspot (Carleton, 2017) will be threatened in the future due to variation of precipitation and increasing trends of temperature. Furthermore, such investigation derived from ancillary data along with remote sensing and GIS provide a concrete conception of a paradigm shift in approach for implementing the synergic strategy such as "Climate Smart Agriculture" urgently in prevailing new climate change reality to socio-economic deprived people and farmer inhabitant in different sections of the India for achieving socio-economic and climate resilience. 


\section{References}

Abatzoglou J.T., Dobrowski S.Z., Parks S.A. \& Hegewisch K.C., 2018, TerraClimate a high-resolution global dataset of monthly climate and climatic water balance from 1958-2015. Scientific Data 5: 1-12. (https://doi. org/10.1038/sdata.2017.191).

Agarwal B., 2013, Food security, productivity, and gender inequality. The Oxford Handbook of Food, Politics, and Society. (https://doi.org/10.1093/oxfordhb/9780195397772.013.002).

Aggarwal R., 2018, Declining soil fertility: Indian agriculture needs renewed focus on soil health. (https:// www.worldofchemicals.com/media/declining-soil-fertility-indian-agriculture-needs-renewed-focus-on-soilhealth/738.html), [Accessed on 20th November 2018].

Ahmad F. \& Goparaju L., 2017, Land Evaluation in terms of Agroforestry Suitability, an Approach to Improve Livelihood and Reduce Poverty: A case study of Palamu district, Jharkhand, India. Ecological Questions 25: 67-84. (http://dx.doi.org/10.12775/EQ.2017.006).

Ahmad F., Goparaju L. \& Qayum A., 2019a, Geo-spatial perspective of vegetation health evaluation and climate change scenario in India. Spat. Inf. Res. (https://doi. org/10.1007/s41324-018-00231-3).

Ahmad F., Uddin M.M. \& Goparaju L., 2019b, Analysis of forest health and socioeconomic dimension in climate change scenario and its future impacts: Remote sensing and GIS approach. Spat. Inf. Res. (https://doi. org/10.1007/s41324-019-00245-5).

Ahmad F., Uddin M.M. \& Goparaju L., 2018, An evaluation of vegetation health and the socioeconomic dimension of the vulnerability of Jharkhand state of India in climate change scenarios and their likely impact: A geospatial approach. Environmental \& Socio-economic Studies 6(4): 39-47. (doi: 10.2478/environ-2018-0026).

Bhushan C., 2015, India is not prepared to tackle climate change impacts. (https://www.downtoearth.org.in/ blog/india-is-not-prepared-to-tackle-climate-changeimpacts-43888).

Carleton T.A., 2017, Crop-damaging temperatures increase suicide rates in India. PNAS 114(33): 8746-8751. (https://doi.org/10.1073/pnas.1701354114).

Carlson K.M., Gerber J.S., Mueller N.D., Herrero M., MacDonald G.K., Brauman K., Havlik P., O'connell Ch.S., Johnson J., Saatchi S.S., West P.C., 2016, Greenhouse gas emissions intensity of global croplands. Nature Climate Change 7(1): 63-68. (doi:10.1038/nclimate3158).

CGIAR, 2012, Agriculture and Food Production Contribute Up to 29 Percent of Global Greenhouse Gas Emissions According to Comprehensive Research Papers. (https://ccafs.cgiar.org/news/press-releases/agriculture- and-food-production-contribute-29-percent-globalgreenhouse-gas\#.XIkmYigzY2w).

Chakraborty A., Seshasai M.V.R., Reddy C.S. \& Dadhwal V.K., 2018, Persistent negative changes in seasonal greenness over different forest types of India using MODIS time series NDVI data (2001-2014). Ecological Indicators 85: 887-903. (https://doi.org/10.1016/j. ecolind.2017.11.032).

Corner-Dolloff C., 2014, Climate-smart agriculture investment prioritization framework. Presentation at COP 20, Lima, Peru. (http://es.slideshare.net/ciatdapa/ climatesmart-agriculture-investment-prioritizationframework).

Dearing J., Battarbee R., Dikau R., Larocque I. \& Oldfield F., 2006, Human-environment interactions: learning from the past. Regional Environmental Change 6: 1-16.

Diwakar S., Surinder K. \& Das A.K., 2017, Long Term Rainfall Trend over Meteorological Sub Divisions and Districts of India. MAUSAM 68(3): 439-450. (doi: 10.13140/RG.2.1.3908.4409).

Ellis E.C., Klein Goldewijk K., Siebert S., Lightman D. \& Ramankutty N., 2010, Anthropogenic transformation of the biomes, 1700 to 2000. Glob. Ecol. Biogeogr.19: 589-606. (https://doi.org/10.1111/j.14668238.2010.00540.x).

Ellis E.C., Goldewijk K.K., Siebert S., Lightman D. \& Ramankutty N., 2013, Anthropogenic Biomes of the World, Version 2, 2000. Palisades, NY: NASA Socioeconomic Data and Applications Center (SEDAC). (http://sedac.ciesin.columbia.edu/downloads/maps/ anthromes/anthromes-anthropogenic-biomes-worldv2-2000/anthromes-v2-2000-asia.png).

FAO, 2010, "Climate-Smart" Agriculture Policies, Practices and Financing for Food Security, Adaptation and Mitigation; Food and Agriculture Organization of the United State of America (FAO): Rome, Italy, 2010; pp. 1-49. (http://www.fao.org/docrep/013/i1881e/ i1881e00.htm), [Accessed on 20th November 2018].

FAO, 2012, Climate Smart Agriculture Sourcebook. (http:// www.fao.org/climate-smart-agriculture-sourcebook/ production-resources/module-b1-crops/chapter-b1-2/ en/), [Accessed on 22 Jan 2019].

FAO, 2019, http://www.fao.org/faostat/en/\#country/100, [Accessed on 22 Jan 2019].

Fick S.E. \& Hijmans R.J., 2017, WorldClim 2: New 1-km spatial resolution climate surfaces for global land areas. International Journal of Climatology 37(12): 43024315.

Goparaju L. \& Ahmad F., 2019, Analyzing the risk related to climate change attributes and their impact, a step towards climate-smart village (CSV): a geospatial approach to bring geoponics sustainability in India. Spat. Inf. Res. (https://doi.org/10.1007/s41324-019-00258-0). 
Goswami B.N., Venugopal V., Sengupta D., Madhusoodanam M.S. \& Xavier P.K., 2006, Increasing trends of extreme rain events over India in a warming environment. Science 314: 1442-1445.

Goswami B.N., Venugopal V., Sengupta D., Madhusoodanan M.S. \& Xavier P.K., 2016, Increasing trend of extreme rain events over India in a warming environment. Science Dec 1, 314(5804): 1442-1444. (doi: 10.1126/ science.1132027).

Howland F., Andrieu N. \& Bonilla-Findji O., 2018, Understanding socioeconomic aspects influencing CSA adoption. CCAFS Working Paper No. 247. Wageningen, The Netherlands: CGIAR Research Program on Climate Change, Agriculture and Food Security (CCAFS). [Available online at www.ccafs.cgiar.org.].

Indexmundi, 2019, https://www.indexmundi.com/agricult ure/?commodity $=$ cattle $\&$ graph $=$ production. [Accessed in $11 / 04 / 2019]$.

IPCC, 2007, "Climate change: the physical science basis. Summary for policymakers," Contribution of Working Group I to the Fourth Assessment Report of the Intergovernmental Panel on Climate Change, IPCC Secretariat, Geneva, Switzerland.

IPCC, 2014, Climate change 2014: Synthesis Report. Contribution of Working Groups I, II and III to the Fifth Assessment Report of the Intergovernmental Panel on Climate Change [Core Writing Team, R.K. Pachauri and L.A. Meyer, (eds.)]. IPCC, Geneva, Switzerland, $151 \mathrm{pp}$.

Josh K.E., 2018, Deadliest India floods in recent history - and what caused them. (https://globalnews.ca/ news/4411144/india-worst-floods/), [Accessed on 20th November 2018].

Khatri-Chhetri A., Regmi P.P., Chanana N. \& Aggarwal P.K., 2019, Potential of climate-smart agriculture in reducing women farmers' drudgery in high climatic risk areas. Climatic Change (https://doi.org/10.1007/ s10584-018-2350-8).

Kumar D., 2017, River Ganges: historical, cultural and socioeconomic attributes. Aquatic Ecosystem Health and Management 20(1): 8-20.

Kumar R. \& Ambastha K., 2016, Wetlands of the Ganga-Brahmaputra Basin, [in:] C. Finlayson, G. Milton, R. Prentice, N. Davidson (eds.), The Wetland Book. Springer, Dordrecht.

Kumar B.M. \& Takeuchi K., 2009, Agroforestry in the Western Ghats of peninsular India and the satoyama landscapes of Japan: a comparison of two sustainable land use systems. Sustain. Sci. 4: 215. (https://doi. org/10.1007/s11625-009-0086-0).

Kumar V., Jain S.K. \& Singh Y., 2010, Analysis of long term precipitation trends in India. Hydrol. Sci. J. 55(4): 484-496.
Lal M., Cubasch U., Voss R. \& Waszkewitz J., 1995, Effect of transient increases in greenhouse gases and sulphate aerosols on monsoon climate. Current Sci. 69(9): 752-763.

Lewis M.W., 2013, Remapping Poverty in India. (http:// www.geocurrents.info/geonotes/remapping-poverty-inindia), [Accessed on 22 Jan 2019].

Lipper L., Thornton P., Campbell B.M., Baedeker T., Braimoh A., Bwalya M., Caron P., Cattanea A., Garrity D., Henry K., Hottle R., Jackson L., Jarvis A., Kossam F., Mann W., McCarthy N., Meybeck A., Neufeldt H., Remington T., Sen P.T., Sessa R., Shula R., Tibu A. \& Torquebiau E.F., 2014, Climate-smart agriculture for food security. Nature Climate Change 4(12): 10681072. (http://dx.doi.org/10.1038/nclimate2437).

Menon P., Deolalikar A. \& Bhaskar A., 2009, India State Hunger Index: Comparisons of Hunger across States. Jointly published by the International Food Policy Research Institute, Welt Hunger Hilfe, and Univ. California Riverside; Washington, DC, Bonn, Riverside.

Minj H.P., 2013, Social dimension of climate change on tribal societies of Jharkhand. International Journal of Social Science \& Interdisciplinary Research 2(3): 34-41.

Oldeman L.R., Hakkeling R.T.A. \& Sombroek W.G., 1991, World Map of the Status of Human-Induced Soil Degradation: An explanatory Note (rev. ed.). UNEP and ISRIC, Wageningen. (https://isric.org/isric/webdocs/docs/ ExplanNote.pdf).

Pandey K., 2018, Hotter than normal: trends show that it is true for both summer and winter temperature. (https:// www.downtoearth.org.in/news/climate-change/hotterthan-normal-trends-show-that-it-is-true-for-both-summer-and-winter-temperature-60352).

Pangaluru K., Velicogna I., Aa G., Mohajerani Y., Ciracì E., Cpepa S., Basha G. \& Rao S.V.B., 2019, Soil Moisture Variability in India: Relationship of Land Surface-Atmosphere Fields Using Maximum Covariance Analysis. Remote Sensing 11(3): 335. (https://doi. org/10.3390/rs11030335).

Patra N.K. \& Babu S.C., 2017, Mapping Indian Agricultural Emissions: Lesson $\mathrm{s}$ for food system transformation and policy support for climate-smart agriculture. International Food Policy Research Institute, IFPRIWashington, DC, USA, IFPRI Discussion Paper 01660, $39 \mathrm{pp}$.

Prasanna V, 2014, Impact of monsoon rainfall on the total foodgrain yield over India. J. Earth Syst. Sci. 123(5): 1129-1145.

Ramanathan V., Chung C., Kim, D., Bettge T., Buja L., Kiehl J.T., Washington W.M., Fu Q., Sikka D.R. \& Wild M., 2005, Atmospheric brown clouds: impacts on South Asian climate and hydrological cycle. Proceed- 
ings of National Academy of Sciences of the United States of America 102: 5326-5333.

Robock A., 2015, Hydrology, floods and droughts|soil moisture. encyclopedia of atmospheric sciences, 2nd edn, pp 232-239. (https://doi.org/10.1016/B978-0-12382225-3.00169-9).

Reichert J.M., Benites J.R.,\& Dalvan R., 2019, Soil moisture and structure as key factors for crop production. (https://www.researchgate.net/publication/265239919 SOIL_MOISTURE_AND_STRUCTURE_AS_KEY FACTORS_FOR_CROP_PRODUCTION).

Sadashiv K.R., 2015, Farmers Suicide in India- Causes and Remedies: 2006-2010. Journal of Economics and Sustainable Development 6(1): 1-8.

Sebastian C., 2019, Soil moisture, a key to better agricultural yield. (http://satyukt.com/soil-moisture-a-key-tobetter-agricultural-yield/).

Sharma D.C., 2018, Rising temperature: India is warming up rapidly. (https://www.thehindubusinessline.com/ news/science/rising-temperature-india-is-warmingup-rapidly/article23893591.ece), [Accessed on 20th November 2018].

Sharma S., 2009, Rethinking watershed development in India: strategy for the twenty first century, [in:] M. Achouri, K. Tennyson, K. Upadhyay, R. White (eds.), Proceedings of Asian Regional Workshop on Water Management, Preparing for Next Generation Watershed Development Programs and Projects, 11-13 September 2003. Food and Agriculture Organization, Rome, Kathmandu.

Shiao T., Maddocks A., Carson C. \& Loizeaux L., 2015, 3 Maps Explain India’s Growing Water Risks. (https:// www.wri.org/blog/2015/02/3-maps-explain-india-sgrowing-water-risks), [Accessed on 20th November 2018].

Sikka A.K., Islam A. \& Rao K.V., 2018, ClimateSmart Land and Water Management for Sustainable Agriculture. Irrigation and Drainage 67(1): 72-81. (https://doi.org/10.1002/ird.2162).

Tyalagadi M., Gadgil A. \& Krishnakumar G., 2015, Monsoonal Droughts In India - A Recent Assessment. Papers on Global Change 22(1): 19-35. (https://doi. org/10.1515/igbp-2015-0013).

WEF, 2018, Why India is most at risk from climate change. (https://www.weforum.org/agenda/2018/03/india-mostvulnerable-country-to-climate-change).

WFP, 2019, World food programme. (https:/www1.wfp. org/countries/india), [Accessed on 22 Jan 2019].

World Bank, 2013, India: Climate Change Impacts. (http:// www.worldbank.org/en/news/feature/2013/06/19/ india-climate-change-impacts).

World Bank, 2018, Climate-Smart Agriculture. (https:// www. worldbank.org/en/topic/climate-smartagriculture).

World Bank Group, FAO and IFAD, 2015, Gender in Climate Smart Agriculture. (https://www.ifad.org/ documents/38714170/39155702/gender_climate_ smart.pdf/8fa21751-5134-417b-af8d-ed84d2e203b3).

Zhao G. \& Siebert S., 2015, Season-wise irrigated and rainfed crop areas for India around year 2005. MyGeoHUB. (doi:10.13019/M2CC71).

http://www.fao.org/docrep/t1696e/t1696e02.htm 